\title{
Activity of Cell Wall-Bound and Cytosolic Peroxidases under the Aftereffect of Copper Ions \\ in Nicotiana tabacum Plants
}

\author{
Anastasia S. Tugbaeva*, Alexander A. Ermoshin, \\ Dmitriy S. Plotnikov and Irina S. Kiseleva \\ Ural Federal University \\ Ekaterinburg, Russian Federation
}

Received 26.04.2021, received in revised form 15.07.2021, accepted 24.08.2021

\begin{abstract}
The adaptation of plants to an excess of heavy metals in the environment and their recovery after elimination of the stressor is of interest in connection with the large-scale pollution of ecosystems and their remediation. This study is aimed at the aftereffect of copper ions (100 and $300 \mu \mathrm{M})$ in plants of Nicotiana tabacum L. The level of plant stress markers (concentration of hydrogen peroxide, activity of class III peroxidases - benzidine and guaiacol, their isoforms) during the recovery period after the removal of copper ions from the environment was evaluated in pretreatment by copper ions of different concentration and the use of control plants. During the recovery period, the concentration of hydrogen peroxide in plant organs (root, stem, and leaves) was high compared to the control. The responses of the roots and shoots under the aftereffect of the stressor were different. The activity of cytosolic guaiacol peroxidase and cell wall-bound peroxidases in root tissues increased according to the increase in $\mathrm{H}_{2} \mathrm{O}_{2}$. In plants pretreated with a lower copper concentration, the activity of cell wall-bound peroxidases in the stem and cytosolic and cell wall-bound benzidine peroxidases in leaves increased. In contrast, pretreatment with a high copper concentration led to a decrease in the activity of peroxidases during the period of plant recovery. Thus, plant organs differed in the content of $\mathrm{H}_{2} \mathrm{O}_{2}$ and the activity of class III peroxidases localized in different compartments (apoplast and cytosol) and in their ability to recover after the removal of the stressor.
\end{abstract}

Keywords: copper ions, Nicotiana tabacum, hydrogen peroxide, peroxidases, recovery.

Acknowledgements. The work was supported by the Ministry of Science and Higher Education of the Russian Federation, Project No. FEUZ-2021-0014.

(C) Siberian Federal University. All rights reserved

This work is licensed under a Creative Commons Attribution-NonCommercial 4.0 International License (CC BY-NC 4.0).

* Corresponding author E-mail address: anastasia.tugbaeva@gmail.com ORCID: 0000-0001-9231-3650 (Tugbaeva A.); 0000-0003-2784-4898 (Ermoshin A.); 0000-0001-9980-4161 (Plotnikov D.); 0000-0002-8709-5203 (Kiseleva I.) 


\title{
Активность ассоциированных с клеточной стенкой и цитозольных пероксидаз в условиях последействия ионов меди в растениях Nicotiana tabacum
}

\author{
А. С. Тугбаева, А.А. Ермошин, \\ Д.С. Плотников, И.С. Киселева \\ Уральский федеральный университет \\ Российская Федерачия, Екатеринбург
}

\begin{abstract}
Аннотация. Адаптация растений к избытку тяжелых металлов в среде и их восстановление после элиминации стрессора представляют интерес в связи с масштабным загрязнением экосистем. Наше исследование направлено на изучение последействия ионов меди $(100$ и $300 \mu \mathrm{M})$ в растениях Nicotiana tabacum L. Оценивался уровень маркеров стресса растений (содержание пероксида водорода, активность пероксидаз III класса - бензидиновой и гваяколовой, их изоформы) в период их восстановления после удаления ионов меди из среды. Выявлено увеличение концентрации пероксида водорода в тканях корня, стебля и листьев. Реакции корня и побега в условиях последействия стрессора различались. Активность цитозольной гваяколовой пероксидазы и ассоциированных с клеточной стенкой пероксидаз в тканях корня повышалась на фоне увеличения содержания $\mathrm{H}_{2} \mathrm{O}_{2}$. Увеличение активности ассоциированных с клеточной стенкой пероксидаз в стебле, цитозольной и ассоциированной с клеточной стенкой бензидиновой пероксидазы в листьях наблюдали у растений, предобработанных более низкой концентрацией меди. Предварительная обработка высокой концентрацией меди, наоборот, приводила к снижению активности пероксидаз в период восстановления растений. Таким образом, органы растений различались по содержанию $\mathrm{H}_{2} \mathrm{O}_{2}$ и активности пероксидаз III класса, локализованных в разных компартментах (апопласт и цитозоль), и по способности восстанавливаться после снятия действия стрессора.
\end{abstract}

Ключевые слова: ионы меди, Nicotiana tabacum, пероксид водорода, пероксидазы, восстановление.

Благодарности. Работа выполнена при поддержке Министерства науки и высшего образования Российской Федерации, проект № FEUZ-2021-0014.

Цитирование: Тугбаева, А.С. Активность ассоциированных с клеточной стенкой и цитозольных пероксидаз в условиях последействия ионов меди в растениях Nicotiana tabacum / А. С. Тугбаева, А. А. Ермошин, Д. С. Плотников, И. С. Киселева // Журн. Сиб. федер. ун-та. Биология, 2021. 14(3). С. 318-327. DOI: 10.17516/1997-1389-0353 


\section{Introduction}

Copper, an essential trace element for plants, is necessary for enzyme activity, photosynthetic and respiratory electron carriers, chlorophyll biosynthesis, and nitrogen assimilation at low concentrations (Jouili et al., 2008; Ali et al., 2006). Excessive amounts of copper have a toxic effect: the efficiency of the electron transport chains in mitochondria and chloroplasts, organ biomass and size, and plant productivity decrease (Jouili et al., 2008; Lin et al., 2005). Many studies have been devoted to the study of plant responses to copper stress; however, there is much less information on plant recovery after the removal of stressors. Even after the copper ions were removed from the medium, they were transported from old organs to young organs and from cell walls to the protoplast, which can contribute to the development of oxidative processes in different organs even after the stressor is removed (Printz et al., 2016).

High concentrations of copper ions, like any stressor, provoke the formation of reactive oxygen species (ROS), including hydrogen peroxide. Antioxidant enzymes such as class III peroxidases (EC1.11.1.7), which include guaiacol (GPO) and benzidine (BPO) peroxidases, are involved in hydrogen peroxide metabolism. These antioxidant enzymes have an affinity for a wide range of oxidizable substrates and are localized in vacuoles and apoplasts, which distinguishes them from class I peroxidases (ascorbate peroxidase EC1.11.1.11, glutathione peroxidase - EC1.11.1.9) located in chloroplasts, peroxisomes and cytoplasm (Veljovic Jovanovic et al., 2018). The activity of class III peroxidases specifically changes during plant development and depends on the type of plant tissue, the availability of substrates, and the strength and duration of the stress (Dragišić Maksimovic et al., 2008).

Apoplastic peroxidases use hydrogen peroxide and phenolic compounds as substrates, thereby maintaining the redox balance in plant cell walls and participating in the formation of monolignol radicals as monomers for lignin polymerization. Cytosolic isoforms of peroxidases, together with other antioxidant enzymes (superoxide dismutase, catalase, class I peroxidases), are involved in maintaining the ROS level in the protoplast, catabolism of auxins and anthocyanins, and porphyrin metabolism (Chamseddine et al., 2009).

Hydrogen peroxide is a more stable and long-lived molecule than other ROS (Schmitt et al., 2014). When transported across the plasma membrane, hydrogen peroxide can accumulate in the cell wall and cause a change in $\mathrm{pH}$, which regulates the activity of apoplast enzymes through conformational rearrangements and phosphorylation (Jouili, El Ferjani, 2004). An increase in the hydrogen peroxide content at the stage of recovery in Glycine max L. plants pretreated with $\mathrm{Cd}^{2+}$ is considered one of the symptoms of toxicity (Holubek et al., 2020).

The optimum $\mathrm{pH}$ for GPO is $6.0-7.0$, while the optimum $\mathrm{pH}$ for $\mathrm{BPO}$ is 5.0; therefore, these peroxidases are referred to as neutral and anionic isoforms, respectively. The role of class III peroxidases in the metabolism of hydrogen peroxide, which is formed under the action of an excess of heavy metals, has been shown in the plants Helianthus annuus L., G. max, and Arabidopsis thaliana L. (Jouili, El Ferjani, 2003; Lin et al., 2005).

The aim of our work was to study the aftereffect of different concentrations of copper ions on the activity of cell wall-bound and cytosolic peroxidases in Nicotiana tabacum L. in a long-term experiment.

\section{Materials and methods}

Plants of N. tabacum, cv. Petite Havana, line SR1 were cultivated on a preautoclaved substrate - a mixture of perlite: vermiculite in a 1:1 ratio, on Knop medium with the addition of 100 (variant 1) and 300 (variant 2) $\mu \mathrm{M} / \mathrm{L} \mathrm{CuSO}_{4}$ 
and Knop medium as the control during the first 20 days after germination, followed by cultivation on Knop medium until reaching the age of 40 days. The plants were grown under conditions of a $16 / 8$ photoperiod and a temperature of $23{ }^{\circ} \mathrm{C}$.

The dry weight of plants was determined gravimetrically after fixing the material at $110{ }^{\circ} \mathrm{C}$ and drying it at $70{ }^{\circ} \mathrm{C}$ to constant weight. For each group, 30 plants were used.

The activity of enzymes guaiacol peroxidase (GPO, EC1.11.1.7) and benzidine peroxidase (BPO, EC1.11.1.7) and the content of hydrogen peroxide were determined spectrophotometrically on a Shimadzu UV-1800 (Shimadzu, Japan) in three biological and five analytical replicates. To obtain the supernatant, weighed samples of roots, stems, and leaves were homogenized in the cold in $0.05 \mathrm{M}$ Tris$\mathrm{HCl}$ buffer ( $\mathrm{pH}$ 7.0) and centrifuged at $4{ }^{\circ} \mathrm{C}$, and the extraction procedure was repeated twice. The resulting supernatant was used to measure the activity of cytosolic enzymes and the amount of hydrogen peroxide. To determine the activity of the cell wall-bound form of the enzyme, the precipitate after extraction of cytosolic enzymes was resuspended twice and centrifuged in 0.05 $\mathrm{M}$ Tris-HCl buffer ( $\mathrm{pH}$ 7.0) supplemented with 1 $\mathrm{M} \mathrm{KCl}$ (Jamet et al., 2006).

The BPO activity was determined spectrophotometrically as the rate of the oxidation reaction of benzidine in the presence of $\mathrm{H}_{2} \mathrm{O}_{2}$ at $\mathrm{pH} 5.0$ and is expressed in relative units/ mg protein $\times$ min (Goldfischer, Essner, 1969). The GPO activity was calculated as the rate of guaiacol oxidation using $\mathrm{H}_{2} \mathrm{O}_{2}$ as a substrate at $\mathrm{pH} 7.0$ and was expressed in $\mathrm{mM}$ guaiacol/ mg protein $\times$ min (Chance, Maehly, 1955). The protein content was determined according to Bradford (1976) using bovine serum albumin as a standard. Protein electrophoresis was performed under nondenaturing conditions in a $10 \%$ polyacrylamide gel. Peroxidase isoforms were detected by a modified method (Lee et al., 2007): the gels were stained for 10 minutes in a reaction medium consisting of $0.2 \%$ benzidine, $0.2 \%$ guaiacol, and $2 \%$ acetic acid. To remove excess substrate, gels were washed in $2 \%$ acetic acid, then they were incubated for 3 minutes in $0.5 \%$ hydrogen peroxide solution until clear bands appeared on an unstained background.

The amount of $\mathrm{H}_{2} \mathrm{O}_{2}$ was determined by the method based on the oxidation of xylenol orange chelates with iron(III) ions with hydrogen peroxide and was expressed in $\mu \mathrm{M}$ hydrogen peroxide/g dry weight (Bellincampi et al., 2000).

Statistical analysis was performed using STATISTICA 10 for Windows 10. Student's $t$-test was used for morphometric parameters, and the Mann-Whitney $U$-test was used for biochemical parameters. Correlations were estimated according to Spearman's nonparametric $R$-test.

\section{Results}

The level of oxidative stress in different organs of $N$. tabacum plants during the recovery period after exposure to different concentrations of $\mathrm{Cu}^{2+}$ was estimated by the content of $\mathrm{H}_{2} \mathrm{O}_{2}$ (Table 1). Compared to the control, the amount of hydrogen peroxide increased 2.1 and 4.5 times in the root, 1.4 and 1.6 times in the stem, and 1.4 and 2.3 times in the leaf in variants 1 and 2 , respectively (the difference was statistically significant at $p=0.03$ ).

To elucidate the role of peroxidase isoforms in the metabolism of hydrogen peroxide and adaptation of $N$. tabacum plants pretreated with high concentrations of copper ions, the activity of cytosolic (Fig. 1, A and B) and cell wallbound isoforms of peroxidases (Fig. 1, C and D) were analyzed. Peroxidases were most active in the root tissues; in leaves, their activity in all variants of the experiment was lower. During the aftereffects of 100 and $300 \mu \mathrm{M} \mathrm{Cu}^{2+}$, the activity of cytosolic GPO in roots increased significantly, 
Table 1. Hydrogen peroxide content in tissues of $N$. tabacum plants after recovery from copper stress. The data are expressed as the mean with standard error.

\begin{tabular}{|c|c|c|c|}
\hline \multirow{2}{*}{ Sample } & \multicolumn{3}{|c|}{$\mathrm{H}_{2} \mathrm{O}_{2}, \mu \mathrm{M} / \mathrm{g}$ dry weight } \\
\cline { 2 - 4 } & Root & Stem & Leaf \\
\hline Control $($ Knop medium $)$ & $0.71 \pm 0.04$ & $3.50 \pm 0.07$ & $8.43 \pm 0.08$ \\
\hline Variant 1 $\left(100 \mu \mathrm{M} \mathrm{Cu}^{2+}\right)$ & $1.53 \pm 0.13^{*}$ & $4.90 \pm 0.19^{*}$ & $11.83 \pm 0.36^{*}$ \\
\hline Variant 2 $\left(300 \mu \mathrm{M} \mathrm{Cu}^{2+}\right)$ & $3.22 \pm 0.02^{*_{a}}$ & $5.56 \pm 0.17^{*}$ & $19.85 \pm 0.23^{*_{a}}$ \\
\hline
\end{tabular}

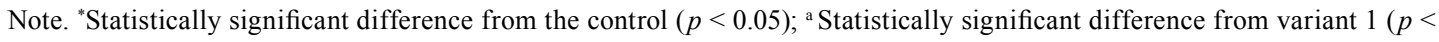
0.05) (Mann-Whitney $U$-test).
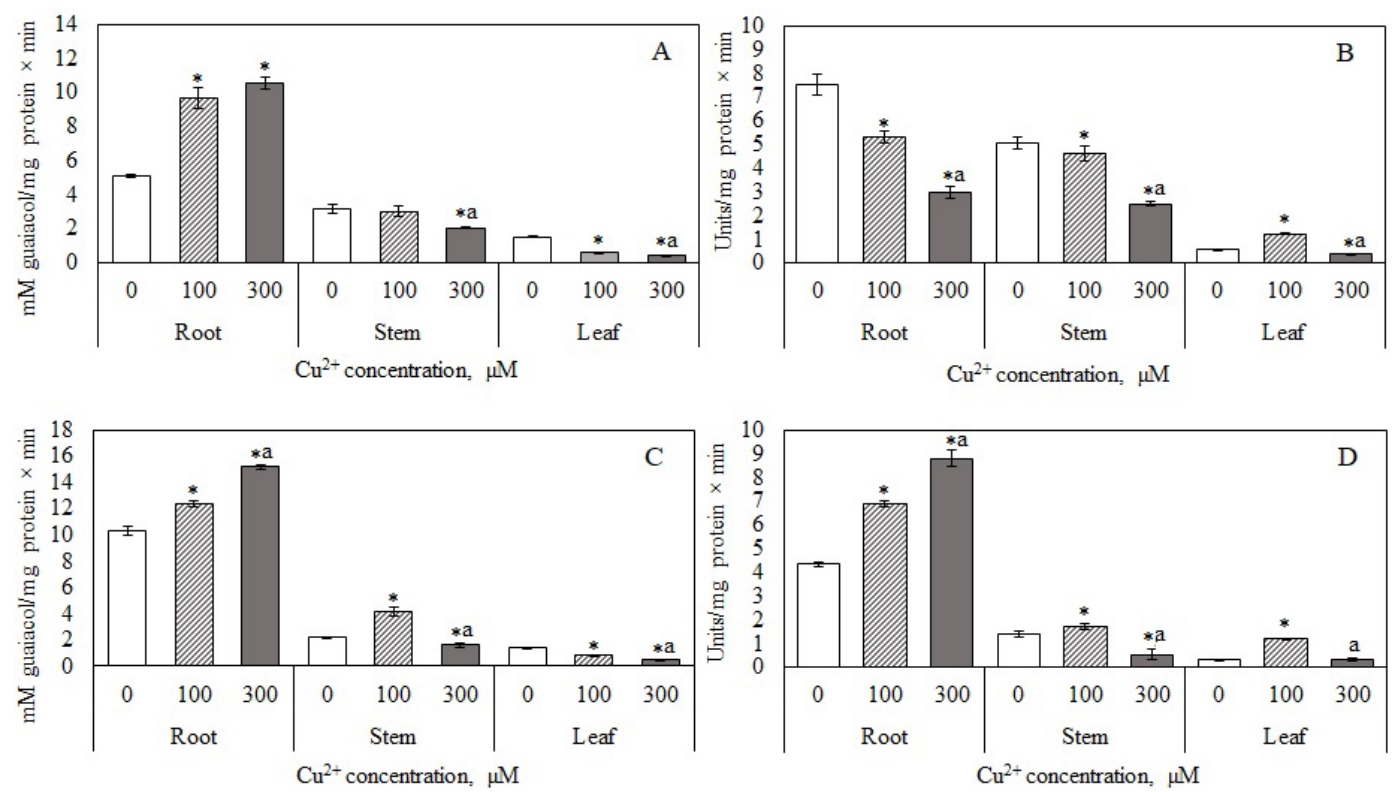

Fig. 1. Enzyme activities in N. tabacum organs after copper stress recovery: A - cytosolic guaiacol peroxidase; $\mathrm{B}$ - cytosolic benzidine peroxidase; $\mathrm{C}$ - cell wall-bound guaiacol peroxidase; D - cell wall-bound benzidine peroxidase. On the $\mathrm{X}$-axis - copper ion concentration, $\mu \mathrm{M}$; on the $\mathrm{Y}$-axis - enzyme activity. The data are expressed as the mean with standard error. *Statistically significant difference from the control $(p<0.05)$; a statistically significant difference from variant $1(p<0.05)$ (Mann-Whitney $U$-test)

by 90 and $106 \%$, respectively (Fig. 1, A). In contrast, the activity of cytosolic BPO decreased (Fig. 1, B) by 30 and $60 \%$ relative to the control in variants 1 and 2 , respectively (the difference was significant, $p=0.01$ ).

In the stems of plants pretreated with 100 $\mu \mathrm{M} \mathrm{Cu}{ }^{2+}$, the activity of cytosolic GPO and BPO did not change. In the case of pretreatment with $300 \mu \mathrm{M} \mathrm{Cu}^{2+}$, their activity decreased by 36 and $51 \%$, respectively (the difference was statistically significant, $p=0.03$ ).
At the stage of recovery, a decrease in the activity of cytosolic GPO observed in leaves was 58 and $73 \%$ compared to the control in variants 1 and 2, respectively. The activity of cytosolic BPO upon pretreatment with $100 \mu \mathrm{M}$ $\mathrm{Cu}^{2+}$ significantly increased 2.1 times; however, the activity decreased by $37 \%$ in the case of pretreatment with $300 \mu \mathrm{M} \mathrm{Cu}^{2+}$.

The activity of cell wall-bound GPO (Fig. 2, C) and BPO (Fig. 2, D) in roots increased radically during the aftereffect period of high 


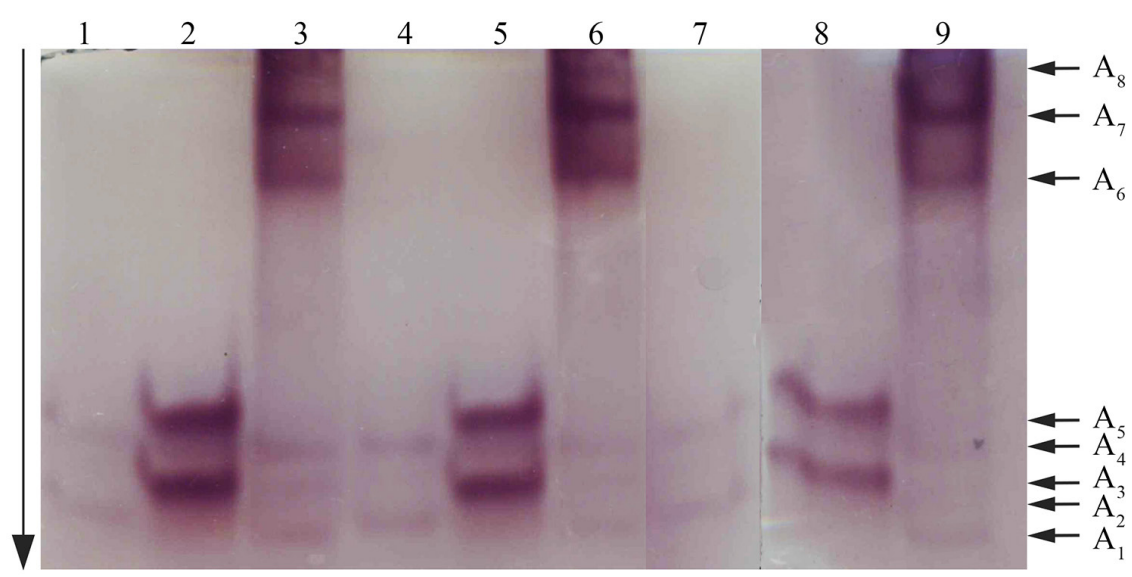

Fig. 2. Isoforms of cytosolic peroxidase in $N$. tabacum organs after copper stress recovery: the arrow indicates the direction of current flow; 1 - leaf, control $\left(0 \mu \mathrm{M} \mathrm{Cu}^{2+}\right) ; 2$ - stem, control $\left(0 \mu \mathrm{M} \mathrm{Cu}^{2+}\right) ; 3$ - root, control $(0 \mu \mathrm{M}$ $\left.\mathrm{Cu}^{2+}\right) ; 4$ - leaf, variant $1\left(100 \mu \mathrm{M} \mathrm{Cu}^{2+}\right) ; 5$ - stem, variant $1\left(100 \mu \mathrm{M} \mathrm{Cu}^{2+}\right) ; 6$ - root, variant $1\left(100 \mu \mathrm{M} \mathrm{Cu}^{2+}\right)$; 7 - leaf, variant $2\left(300 \mu \mathrm{M} \mathrm{Cu}^{2+}\right) ; 8$ - stem, variant $2\left(300 \mu \mathrm{M} \mathrm{Cu}^{2+}\right) ; 9$ - root, variant $2\left(300 \mu \mathrm{M} \mathrm{Cu}^{2+}\right)$

concentrations of copper ions. In variant 1 in the stem, the activity of GPO increased by $88 \%$ and BPO by $22 \%$ compared to the control (the difference was statistically significant, $p=0.03$ ). In contrast, in variant 2 , a significant decrease in the activity of GPO and BPO was noted as 26 and $62 \%$, respectively (at $p=0.03$ ). In leaf tissues, the activity of peroxidases changed in a different way. The activity of cell wall-bound GPO was comparable to the activity in the control plants in the case of pretreatment with $100 \mu \mathrm{M} \mathrm{Cu}^{2+}$ but significantly decreased in the case of $300 \mu \mathrm{M}$ $\mathrm{Cu}^{2+}$. The BPO activity in variant 1 increased by 3.5 times (the difference was statistically significant, $p=0.03$ ); in variant 2 , the change in activity was not significantly different.

The activity of cytosolic and cell wallbound isoforms of peroxidases in the root tissues was higher than the activity in the stem and leaves (Fig. 1). At the stage of recovery after the copper ions were removed, an increase in the activity of cytosolic GPO and cell wall-bound GPO and BPO was found. However, the activity of cytosolic BPO (Fig. 1, B) decreased in roots and stems, different from the general trend of the effect of pretreatment with copper ions on peroxidase activity in different parts of plants. To explain this fact, protein electrophoresis of cytosolic peroxidases isolated from root, stem, and leaf tissues was performed (Fig. 2). Isoforms $\mathrm{A}_{2}$ and $\mathrm{A}_{4}$ were common in root, stem, and leaf tissues; their activity decreased under stress conditions. Four isoforms of peroxidases were identified in the stem tissues: $\mathrm{A}_{2}-\mathrm{A}_{5}$. In the case of plant pretreatment with $300 \mu \mathrm{M} \mathrm{Cu}^{2+}$, a decrease in enzyme activity was noted. Three specific isoforms, $\mathrm{A}_{6}-\mathrm{A}_{8}$, were found in root tissues. The activity of these three isoforms remained high in all variants of the experiment. We assume that the total BPO activity decreased in root tissues due to a decrease in the activity of $\mathrm{A}_{2}$ and $\mathrm{A}_{4}$ isoforms.

Peroxidase isoforms in roots and shoots were reported to differ in sensitivity to ROS (Dragišić Maksimovic et al., 2008). In our study, at the stage of plant recovery after copper stress, an increase in the content of hydrogen peroxide was accompanied by an increase in the activity of cell wall-bound BPOs (Spearman's correlation coefficient $r=+0.85)$, cell wall-bound $(r=+0.76$ ) and cytosolic GPO $(\mathrm{r}=+0.77)$ in the root and a decrease in the activity of cytosolic BPO 
$(\mathrm{r}=-0.84)$. In the stem, the activity of cytosolic peroxidases decreased with an increase in hydrogen peroxide amount $(\mathrm{r}=-0.66)$. In leaves, no statistically significant correlations were found between $\mathrm{H}_{2} \mathrm{O}_{2}$ production and enzyme activity. The changes in enzyme activity indicate that the plants did not eliminate the symptoms of copper ion toxicity and were still stressed even after the treatment was remote for 20 days. The continuation of stress was also confirmed by the morphometric analysis data. At the stage of recovery after $\mathrm{Cu}^{2+}$ ions were removed from the media, $N$. tabacum plants revealed changes in their growth. The biomass was $0.45 \pm 0.04 \mathrm{~g}$ in the control, $0.50 \pm 0.04 \mathrm{~g}$ in variant $1\left(100 \mu \mathrm{M} \mathrm{Cu}^{2+}\right)$, and $0.34 \pm 0.02 \mathrm{~g}$ in variant $2\left(300 \mu \mathrm{M} \mathrm{Cu}^{2+}\right)$. The plants in variant 1 were comparable to the control group, and in variant 2 , a statistically significant decrease in dry weight by $24 \%$ relative to the control was noted (at $p=0.03$ ).

\section{Discussion}

The level of oxidative stress in different organs can be characterized by the amount of hydrogen peroxide. The data obtained revealed $\mathrm{H}_{2} \mathrm{O}_{2}$ accumulation in different organs of $N$. tabacum pretreated with copper ions, as $\mathrm{Cu}^{2+}$ is a stimulator of ROS production in the Fenton and Haber-Weiss reactions (Elleuch et al., 2013). Most likely, the high level of hydrogen peroxide in plants after a twenty-day recovery period was caused by the redistribution of copper ions between organs and translocation from the cell walls to the protoplast (Printz et al., 2016; Marques et al., 2018). We assumed that high concentrations of $\mathrm{H}_{2} \mathrm{O}_{2}$ in root tissues stimulated the activity of cytosolic and cell wall-bound GPO and cell wall-bound BPO, which could lead to increased lignification of cell walls, binding of $\mathrm{Cu}^{2+}$ by carboxyl, hydroxyl, and other groups of lignin, and a decrease in the translocation of metal ions into the shoot (Bouazizi et al., 2011).
The activity of peroxidases is considered to be a marker of plant resistance to stress factors. The induction of peroxidase activity was shown to be most typical for plants sensitive to an excess of $\mathrm{Cu}^{2+}$ in the medium, while resistant forms of plants are characterized by low peroxidase activity (Bouazizi et al., 2007). Copper ions induced the activity of anionic peroxidases and lignin biosynthesis in the cell walls of the root in H. annuus and G. $\max$ (Jouili, El Ferjani, 2003; Lin et al., 2005). In response to $50 \mu \mathrm{M} \mathrm{Cu}^{2+}$, the activity of cytosolic and apoplastic GPO in the leaves and stems of H. annuus increased (Jouili, El Ferjani, 2004).

The different trends in changes in cytosolic and cell wall-bound BPO activity in root tissues under stress conditions could be a consequence of local changes in the $\mathrm{pH}$ level in the cell walls and cytosol during the recovery period after the removal of the stressor. In Phaseolus vulgaris $\mathrm{L}$., after treatment with 50 and $75 \mu \mathrm{M}$ $\mathrm{Cu}^{2+}$, the activity of apoplastic coniferyl alcohol peroxidase in root tissues increased but decreased in the cytosol (Bouazizi et al., 2011). The authors suggest that under copper-induced stress, the enzyme was transported from the protoplast to the apoplast, which led to a decrease in the activity of the cytosolic form. An increase in the activity of class III peroxidase isoforms associated with the cell wall may indicate the role of lignification as an adaptive response to an excess of copper ions in the medium (Bouazizi et al., 2011). Most likely, similar mechanisms contributed to the induction of the activity of BPO apoplastic isoforms.

Since GPO and BPO have different $\mathrm{pH}$ optima, localize in tissues and differ in affinity to substrates, changes in their activity in different organs and tissues can be a specific reaction in the recovery period after stress. We assume that in roots, copper ions were predominantly deposited in cell walls of the cortex, partially in the vacuoles; in shoots, the content of copper ions 
was higher in the cytoplasm than in the cell walls. The deposition of heavy metals in the vacuole of the parenchymal cells of the cortex and stele in shoots was shown earlier (Printz et al., 2016; Marques et al., 2018). The data obtained showed that physiological and biochemical processes were restored in plants pretreated with $100 \mu \mathrm{M}$ $\mathrm{Cu}^{2+}$, which can be proven by the absence of significant changes in the activity of cytosolic peroxidases compared to the control plants. A decrease in the activity of cell wall-bound and cytosolic enzymes at $300 \mu \mathrm{M} \mathrm{Cu}^{2+}$ may be a consequence of deeper damage to the structure and synthesis of proteins and incomplete plant recovery at 20 days (Bouazizi et al., 2007).

The level of hydrogen peroxide in control and prestressed plants was higher in the leaf tissues and lower in the roots, which may be due to metabolic processes, especially the formation of ROS in light reactions of photosynthesis and in photorespiration. Since there were no correlations between the activity of class III peroxidases and the level of hydrogen peroxide in leaves, we assumed that in leaves, other antioxidant enzymes were involved in maintaining the redox balance, such as class I peroxidases and catalase (Chamseddine et al., 2009; Veljovic Jovanovic et al., 2018).

The observed changes, in particular, the decrease in plant biomass in the case of pretreatment with $300 \mu \mathrm{M} \mathrm{Cu}{ }^{2+}$, indicate that there was not complete recovery of $N$. tabacum plants within 20 days after the removal of the excess copper ions from the media, and the plants did not eliminate the symptoms of toxicity. A decrease in organ biomass is a nonspecific reaction to heavy metal stress. For example,

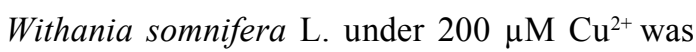
characterized by a decrease in the total mass and mass of individual organs (Khatun et al., 2008). The decrease in dry mass was also described for $P$. vulgaris leaves under treatment with 160 $\mu \mathrm{M} \mathrm{Cu}^{2+}$ (Cook et al., 1997). In Glycine max L. pretreated with higher concentrations of $\mathrm{Cd}^{2+}$, the restoration of shoot and leaf growth and a reduction in root length were described (Holubek et al., 2020). Our data also showed a decrease in the mass of $N$. tabacum plants. We suppose that this effect was associated with the overproduction of ROS and the redistribution of plant resources for the synthesis of enzymes and low molecular weight antioxidants.

\section{Conclusions}

The data obtained revealed that in tobacco plants pretreated with copper ions by 100 or 300 $\mu \mathrm{M} \mathrm{CuSO}_{4}$, the responses of roots, stems, and leaves during the recovery period after stress were different. The aftereffect of excess copper ions led to an increase in the content of hydrogen peroxide in roots and shoots, which indicates the sensitivity of $N$. tabacum to this stressor and incomplete plant recovery in the poststress period. In the case of plant pretreatment with $100 \mu \mathrm{M} \mathrm{Cu}^{2+}$, a specific increase in the activity of cell wall-bound GPO and BPO was observed in the stem, and an increase in the activity of BPO in apoplast and cytosol was observed in the leaves. An increase in cytosolic GPO activity in roots, caused by an increase in $\mathrm{H}_{2} \mathrm{O}_{2}$, led to a decrease in the level of oxidative stress in the cytosol. The increase in cell wall-bound peroxidase activity could lead to the higher formation of monolignol radicals, which, in turn, could cause additional lignification and a partial restriction of copper ion transportation into the shoot. Thus, an increase in the activity of class III peroxidases promoted a decrease in oxidative processes in cells and restoration of plant growth. We assume that plants pretreated with $300 \mu \mathrm{M} \mathrm{Cu}^{2+}$ require a recovery period longer than 20 days, since they retained the markers of copper ion toxicity after the stressor was removed. 
The data obtained indicate the heterogeneity of tissues and organs in response to oxidative stress caused by the action of copper ions in the culture medium. The results show that copper had a long-lasting aftereffect. The accumulation of $\mathrm{H}_{2} \mathrm{O}_{2}$ and the activity of peroxidases depend on the strength of the stress and their tissue localization.

\section{References}

Ali M. B., Singh N., Shohael A. M., Hahn E. J., Paek K. Y. (2006) Phenolics metabolism and lignin synthesis in root suspension cultures of Panax ginseng in response to copper stress. Plant Science, 171(1): 147-154

Bellincampi D., Dipierro N., Salvi G., Cervone F., De Lorenzo G. (2000) Extracellular $\mathrm{H}_{2} \mathrm{O}_{2}$ induced by oligogalacturonides is not involved in the inhibition of the auxin-regulated rolB gene expression in tobacco leaf explants. Plant Physiology, 122(4): 1379-1385

Bouazizi H., Jouili H., El Ferjani E. (2007) Copper-induced oxidative stress in maize shoots (Zea mays L.): $\mathrm{H}_{2} \mathrm{O}_{2}$ accumulation and peroxidases modulation. Acta Biologica Hungarica, 58(2): 209-218

Bouazizi H., Jouili H., Geitmann A., El Ferjani E. (2011) Cell wall accumulation of $\mathrm{Cu}$ ions and modulation of lignifying enzymes in primary leaves of bean seedlings exposed to excess copper. Biological Trace Element Research, 139(1): 97-107

Bradford M. M. (1976) A rapid and sensitive method for the quantitation of microgram quantities of protein utilizing the principle of protein-dye binding. Analytical Biochemistry, 72(1-2): 248-254

Chamseddine M., Wided B. A., Guy H., Marie-Edith C., Fatma J. (2009) Cadmium and copper induction of oxidative stress and antioxidative response in tomato (Solanum lycopersicon) leaves. Plant Growth Regulation, 57(1): 89-99

Chance B., Maehly A.C. (1955) Assay of catalases and peroxidases. Methods in Enzymology, 2: 764-775

Cook C.M., Kostidou A., Vardaka E., Lanaras T. (1997) Effects of copper on the growth, photosynthesis and nutrient concentration of Phaseolus plants. Photosynthetica, 34(2): 179-193

Dragišić Maksimović J., Maksimović V., Živanović B., Hadži-Tašković Šukalović V., Vuletić M. (2008) Peroxidase activity and phenolic compounds content in maize root and leaf apoplast and their association with growth. Plant Science, 175(5): 656-662

Elleuch A., Chaâbene Z., Grubb D.C., Drira N., Mejdoub H., Khemakhem B. (2013) Morphological and biochemical behavior of fenugreek (Trigonella foenum-graecum) under copper stress. Ecotoxicology and Environmental Safety, 98: 46-53

Goldfischer S., Essner R. (1969) Further observations on the peroxidatic activities of microbodies (peroxisomes). Journal of Histochemistry \& Cytochemistry, 17(10): 681-685

Holubek R., Deckert J., Zinicovscaia I., Yushin N., Vergel K., Frontasyeva M., Sirotkin A.V., Bajia D. S., Chmielowska-Bąk J. (2020) The recovery of soybean plants after short-term cadmium stress. Plants, 9(6): 782

Jamet E., Canut H., Boudart G., Pont-Lezica R.F. (2006) Cell wall proteins: a new insight through proteomics. Trends in Plant Science, 11(1): 33-39

Jouili H., Bouazizi H., Rossignol M., Borderies G., Jamet E., El Ferjani E. (2008) Partial purification and characterization of a copper-induced anionic peroxidase of sunflower roots. Plant Physiology and Biochemistry, 46(8-9): 760-767 
Jouili H., El Ferjani E. (2003) Changes in antioxidant and lignifying enzyme activities in sunflower roots (Helianthus annuus L.) stressed with copper excess. Comptes Rendus Biologies, 326(7): 639-644

Jouili H., El Ferjani E. (2004) Effect of copper excess on superoxide dismutase, catalase, and peroxidase activities in sunflower seedlings (Helianthus annuus L.). Acta Physiologiae Plantarum, 26(1): $29-35$

Khatun S., Ali M.B., Hahn E.-J., Paek K.-Y. (2008) Copper toxicity in Withania somnifera: growth and antioxidant enzymes responses of in vitro grown plants. Environmental and Experimental Botany, 64(3): 279-285

Lee B.-R., Kim K.-Y., Jung W.-J., Avice J.-C., Ourry A., Kim T.-H. (2007) Peroxidases and lignification in relation to the intensity of water-deficit stress in white clover (Trifolium repens L.). Journal of Experimental Botany, 58(6): 1271-1279

Lin C. C., Chen L. M., Liu Z.H. (2005) Rapid effect of copper on lignin biosynthesis in soybean roots. Plant Science, 168(3): 855-861

Marques D. M., Veroneze Júnior V., da Silva A. B., Mantovani J. R., Magalhães P. C., de Souza T. C. (2018) Copper toxicity on photosynthetic responses and root morphology of Hymenaea courbaril L. (Caesalpinioideae). Water Air and Soil Pollution, 229(5): 138

Printz B., Lutts S., Hausman J.F., Sergeant K. (2016) Copper trafficking in plants and its implication on cell wall dynamics. Frontiers in Plant Science, 7: 601

Schmitt F.J., Renger G., Friedrich T., Kreslavski V.D., Zharmukhamedov S.K., Los D.A., Kuznetsov V.V., Allakhverdiev S.I. (2014) Reactive oxygen species: re-evaluation of generation, monitoring and role in stress-signaling in phototrophic organisms. Biochimica et Biophysica ActaBioenergetics, 1837(6): 835-848

Veljovic Jovanovic S., Kukavica B., Vidovic M., Morina F., Menckhoff L. (2018) Class III peroxidases: functions, localization and redox regulation of isoenzymes. Antioxidants and antioxidant enzymes in higher plants. Gupta D., Palma J., Corpas F. (eds.) Cham, Springer, p. 269-300 